Jan SANDNER

IEiB UKSW Warszawa

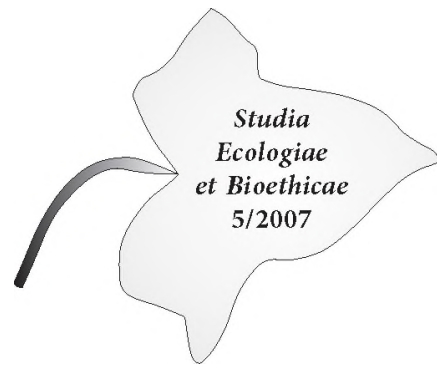

\title{
The essence and metatheoretical problems of "ecological attitudes"
}

\section{Introduction to the "ecological attitude" concept learning genesis}

Problems related with an ecological attitude of our society are not new. Hitherto, national scientific-research centers as well as some independent scholars were occupied with the above said issue. It is a difficult issue, reluctantly undertaken by researchers due to its very interdisciplinary character. This interdisciplinarity, on one hand is its cognitive force on the other, its powerful drawback, its strong limitation. The above is caused by its extensive generality of expression, different scientific workshop, applied terminology and objectives behind the commencement of the said research.

This chaos considerably hinders learning through science these very important problems, hidden beneath the broadly understood term of proecological attitudes. This pertains not only the epistemological problems themselves, related with "ecological awareness", but also what following it, disenables constructing methodological assumptions for performing such research. Research which should be formulated basing on the same rules as in other sciences. Beginning from stating the problem or hypothesis, finishing with formulating laws and explaining phenomena. Of course, our research problem is not a separate cognitive subject, we can only classify it as one of the elements having a real influence on the natural environment, examined within ecology, or sozology. This element in many configurations can play the role of one of the factors of the ecological system. As we know, ecological systems in which the human activity has a considerable role, are very complicated, which causes additional difficulties in applying simple methodological schemas for solving them.

Still, regardless of how complex is the examined system the general rule still applies: the formulated hypotheses must be verifiable through experiments. In the case of our research problem, namely the development of pro-ecological attitudes, the greatest difficulty is to formulate a correct hypothesis, which has a chance to be explained through the collected experimental data. The results 
of such research should be used to solving various causal-effect processes which are all serve the purpose of the condition of the natural environment and its resources.

\section{Epistemology of ecological attitudes}

The very notion of pro-ecological attitudes has not been finally properly defined up to this day. The researchers most often use the definition which Tadeusz Burger from the Instytut na Rzecz Ekorozwoju [Institute for Ecological Development] cites in his report "Świadomość ekologiczna społeczeństwa polskiego u progu XXI wieku" [The ecological awareness of the Polish society at the threshold of the $21^{\text {st }}$ century]. The definition of this concept is "Ecological awareness is a set of information and beliefs on the natural environment and perception of the relations between the state and character of the natural environment, and the conditions and quality of the life of men."

It is difficult to imagine anything more general and undefined. The analysis of this definition does not withstand any test. Already at its first phrasing claiming that "ecological awareness is a set of information and beliefs" is proof of the lack of elementary scientific bases at the stage whilst it has been construed. It is a characteristic complex of creative freedom in understanding the "inflowing information and beliefs" depending on, as it usually happens, the social structure, country of origin or the genetics itself. Can there be anything more general and imprecise?

In the second part of the definition, we read about the so-called "perception of the relations between the state and character of the environment and the conditions and quality of the life of men". In this case, we again deal not only with, gently speaking, a lack of precision but also a lack of pointing out to us what processes exactly the authors have on their minds. Approaching this part of the definition uncritically, we could without much difficulty obtain on its basis results that would be absurd in their nature. Results where the so-called ideal state of the environment, necessary for the proper functioning of man, are fulfilled by for instance an environment, but a city one, and urbanized. Defending this concept, basing strictly on the message carried by this definition, these largest concentrations of population in the urban environment in some sense create for it the best existence conditions. Such, or similar, research results confirming this phenomenon can be encountered in many studies. Yet, such results are achieved exclusively by sociologists for whom the point of reference are completely different elements of scientific cognition than for ecologists.

Many scientists cite in their works various research realized under the aegis "ecological attitudes". But the conclusions from these works are so inconsistent 
and unbelievable that often it is hard to acknowledge them as scientific research. The research is realized by persons of very diversifies education which frequently is visible in the form of obtained results.

A completely different view on the problem matter can be provided by a sociologist (which I have proved before), an ecologist, a geographer or a person with the education profile of environment protection. In some researches, we can also see the influence of the so-called political views.

It is well-known that ecology and environmental protection often become tools in political fight. It is no different with the pro-ecological attitudes. A willingness to display particular attitudes often serves as a peculiar "election argument" for various political environments. Thus, often considerably depreciating the true scientific skills which should apply with this type of researches and analyses.

Coming back to the very essence of the epistemology of the notion of "ecological attitudes", we face a serious dilemma again, what we are supposed to understand as it as a matter of fact. With no possibility of defining this notion, it becomes practically impossible not only to investigate but also to compare the obtained results of researches. The rare scientific works concerning this issue represent very different approaches. If a research work is realized by a sociologist, he understands ecological attitudes as all social and partly economical processes connected with this issue. In this case, these elements will be expressed: the process of unification with the EU, the relations between the countryside and the city, or between the small and the big city. A sociologist will certainly investigate what should in fact be the scientific basis of such research. Are the examined respondents substantially prepared to partake in such researches? I mention it now because in the epistemology of the ecological attitudes, the essence of the problem is, among others, in the so-called examined object itself.

\section{Problems of the methodology of researches on ecological attitudes}

Research of ecological attitudes is what we should understand as the whole process aiming at evaluation of the state of our society's knowledge within the scope of the broadly understood issue of environmental protection. How can we research the ecological attitudes when our society's knowledge on understanding the basic notions of environmental protection or ecology is still simply scarce. This knowledge is still lesser if we try to verify what they know within the scope of understanding the course and significance of the so-called environmental processes. Researching ecological attitudes with regard to understanding the environmental processes, it would soon appear that the knowledge of the respondents would be the lower possible in such research. That is why we should ask the following question: is it possible at all, in a society like ours, representing 
the present substantive knowledge within the scope of the broadly understood issue of environmental protection, to conduct credible research on its proecological, or ecological, attitudes?

It seems that such research are beforehand doomed to a high degree of incredibility. It is as if we asked respondents while filling out questionnaire survey to compare the European Union laws to the enforced laws in our country pertaining to individual regulations on the environmental protection. What can be the result of such a research, what would be the credibility of such research? Can we investigate the ecological attitudes of our society in this way? A society which for 50 years was undergoing the process of indoctrination by the communist system. A society for which the natural environment was merely an endless reservoir of resources that can be freely exploited, regardless of its consequences.

The $20^{\text {th }}$ century man yielded to the old temptation "you shall be like gods" on an unprecedented scale. Philosophers and ideologists aspired to elimination of God and religion from life. They claimed that God is only a product of man, who restricts and limits him. Only devoid of such limitations, man can become free, able to change the image of the Earth. As the transcendent God was eliminated, "new gods", new cults and religions replaced him. One of the most dangerous for humanity was, and is constantly reborn in new forms ever since, the so-called "myth of progress". It stems from the conviction that science and the technology based on it will solve all the problems of men, thus creating a peculiar "earthly paradise".

It occurs that in some sense, the specter of these times begins to repeat again. This time, however, in a completely different form. The threats we are facing presently are certainly comparable to those from the times of communism. At the moment, we are still stuck in the passed period of time, when "man put himself in the place of God", thus leading to annihilation of whole nations, and along with them also of the environmental resources. In these countries, no-one else but the man, putting himself in God's place, wreaked the most havoc in human consciousness..

This peculiar indoctrination process that I mentioned a moment ago, contrary to appearances, has largely affected various pro-social attitudes in our society. One of these attitudes is the very proecological attitude. Actually, we can even risk the opinion that in this attitude we can see as if a reflection a "mirror" the whole period pertaining to the years when the natural environment did not constitute a "partner" for us to build a harmonious development with. It was only, at best, this peculiar abiotic reservoir of potential resources which can be constantly exploited.

Someone who thinks today, that these are times so distant which should not considerably affect the presently forming proecological attitudes, appears to 
be wrong. In our society, even the youngest generation has no properly formed relations with the environment. They have not and cannot have because they did not gain these relations either from school or from the family home. Schools at all levels up to this day have not created a consistent program for developing pro-ecological attitudes. Certain attempts which are carried out in the recent years concern restructuring the substantive program, but this is done exclusively within the traditionally realized subjects, such as: biology or geography.

Activities undertaken among others by professor dr hab. Danuta Cichy are worth our attention. For this, she set up a quarterly "Edukacja Biologiczna i Środowiskowa" [Biological and environmental education], edited by Instytut Badań Edukacyjnych [Institute of educational researches] and Instytut Technologii Eksploatacji [Institute of exploitation technology] with her as the editor. This quarterly is one of the few scientific titles edited in the country, concerning the broadly understood issue of environmental education or development of pro-ecological attitudes. This title is in its substantive assumptions addressed to a receiver who not only searches for supplementary knowledge on the environmental issue but also actively participates in the educational process. I mention this quarterly here not without purpose. The editor-in-chief of the quarterly created it wanting exactly to develop, among others, a pro-ecological awareness among teachers (of all types of schools). That is in the social group which is co-responsible for the development of our youth. The social group which, next to the parents, has an immense significance for the developing of social attitudes.

Will our next generations of youth be properly prepared to understanding the processes of the natural environment together with its resources? The proper development of our country will depend on this.

I now come back to the notion of ecological awareness. If up to this day, in our educational programs for all types of schools proper mechanisms allowing the teachers to perform system teaching within the scope of "perceiving relations between the state and character of the natural environment and the conditions and quality of human life" have not been created, what results of such education can we achieve. If we want to research this phenomenon, then these researches should have a completely different character and methodological dimension. Conducting research for a representative group of our society, basing on the rules applied so far, will not provide us in fact with any substantive information. The information that will arise as a result of such research will not have the expected scientific quality either.

The methodology of teaching in all types of schools in our country not only is not adapted to system teaching, causal-effect changes in the natural environment, but also it does not work even in teaching the basics of environmental protection. The results of such state of knowledge are visible even in the circles of academic 
youth who choose the environmental protection specialty for their studies. Test researches conducted on students (in one of the Warsaw universities) of the faculty with the environmental protection specialty frequently prove a lack of elementary knowledge even at the level of basic notions from the scope of the chosen specialty. The lack of the basic knowledge, already on the initial stage of academic education, considerably disenables correct planning of the educational process of this youth in the system which applies at university.

The process of university education within the scope of environmental protection should be based on the system approach, as well as on methodological approach. Realizing the current educational program in this field at university, there is no possibility of supplementing, during the studies, the knowledge which the students should have gained much earlier, still at the level of education at school. The problem is best illustrated by the researches I mentioned before. I once again stress that they were conducted among the youth which is in a sense an intellectual elite. The respondents were students, which means persons who passed their school-leaving examinations, more, who took studies with the environmental protection specialty in Warsaw. The results of the research confirm the urgent need to seek for new solutions in building an efficient educational system which would supplement the often just basic knowledge on the broadly understood issue of environmental protection. The process should also activate the mechanisms of system perception within the scope of mutual relations found in the natural environment. For which the methodological point of reference should be the highest known level of organization on Earth, that is the level of the Biosphere.

One of the suggested solutions supporting this entire process of education within the scope of a broadly understood environmental protection is the introduction of new interactive educational tools, constructed and next made available through the Internet. Tools, which at least in part, will methodologically supplement gaps created in the basic ecological education system.

\section{Bibliography}

Botkin Daniel, Keller Edward., Environmental Science, John Wiley \& Sons INC, New York 1995 , s.625.

BUrger T., Raport; Świadomość ekologiczna społeczeństwa polskiego u progu XXI wieku, Wydawca Instytut na Rzecz Ekorozwoju, Warszawa 2000, s. 41,

Cichy D., red., kwartalnik rocznik 2005, pt. „Edukacja Biologiczna i Środowiskowa”, wydawany przez Instytut Badań Edukacyjnych oraz Instytut Technologii Eksploatacji, Warszawa 2005.

DoŁĘGA J., M., 1993, Człowiek w zagrożonym środowisku ATK, Warszawa, s.197.

Krebs CH., J., Ekologia, Eksperymentalna analiza rozmieszczenia i liczebności, PWN Warszawa 1996, s.730. 
SANDNER J., Recenzja kwartalnika rocznik 2005, pt. „Edukacja Biologiczna i Środowiskowa”, wydawany przez Instytut Badań Edukacyjnych oraz Instytut Technologii Eksploatacji, Nr.3/2006, Warszawa 2006.

SANDNER J., Idee zrównoważonego rozwoju w holistycznej edukacji przyrodniczej, materiały z Konferencji Naukowej pt. „Ekofilozofia a ochrona środowiska”, Olecko 2006,

SANDNER J., Człowiek a środowisko przyrodnicze; Konflikty społeczno-ekologiczne, Edukacja ekologiczna chrześcijaństwo, wydawnictwo Verbinum, Warszawa 2003,

SANDNER J., Nie wiedza a odpady; Ochrona środowiska społeczno-przyrodniczego w filozofii i teologii, wydawnictwo UKSW, Warszawa 2001,

SANDNer J., Świadomość i edukacja ekologiczna, Wydawnictwo ATK, Warszawa 1998,

SANDNER J., Postawy proekologiczne społeczeństwa polskiego; Ochrona środowiska w filozofii i teologii, Wydawnictwo ATK, Warszawa 1999,

SANDNER J., Internet as source of information about environmental protection, Studia Ecologiae et Bioethicae, t.3, Wydawnictwo UKSW, Warszawa 2006,

SANDner J., The Problems of Environmental Education in Agribusiness, Studia Ecologiae et Bioethicae, t.3, Wydawnictwo UKSW, Warszawa 2006,

SANDNER J., Badania postaw proekologicznych społeczeństwa polskiego, S̉wiadomość i edukacja ekologiczna, Wydawnictwo ATK Warszawa 1998, s. 37-53.

SMUts, J.C., Holism and Evolution, Macmillan Co., New York 1926.

Sychut W., Chmielowski T.J., Świadomość ekologiczna mieszkańców obszarów chronionych, Wydawca Instytut Gospodarki Przestrzennej i Komunalnej w Lublinie, Lublin 1990, s. 74.

Zdyвicka Z.J., Religia i religioznawstwo, Redakcja Wydawnictw KUL, Lublin 1998, s.447.

\section{STRESZCZENIE}

Problemy związane z postawami ekologicznymi naszego społeczeństwa nie są nowe. Problematyką tą dotychczas zajmowały się niezależne ośrodki naukowo-badawcze w kraju, jak również niektórzy niezależni naukowcy. Jest to problematyka trudna, niechętnie podejmowana przez badaczy ze względu na swój bardzo interdyscyplinarny charakter. Ta interdyscyplinarność z jednej strony jest jej siłą poznawczą, z drugiej zaś silnie ją hamująca. Spowodowane jest to daleko idącą ogólnością sformułowań, odmiennym naukowym warsztatem badań, stosowaną terminologią oraz celami dla jakich powstają te badania. Autor w swoim artykule stara się ponownie podejść do epistemologii postaw proekologicznych, jak i samej ich metodologii badań. 